\title{
Source-sink relationships in fruit species: A review
}

\section{Relación fuente-vertedero en especies frutales. Una revisión}

GERHARD FISCHER ${ }^{1,4}$

PEDRO JOSÉ ALMANZA-MERCHÁN²

FERNANDO RAMÍREZ ${ }^{3}$

Fruits and next leaves of avocado.

Photo: G. Fischer

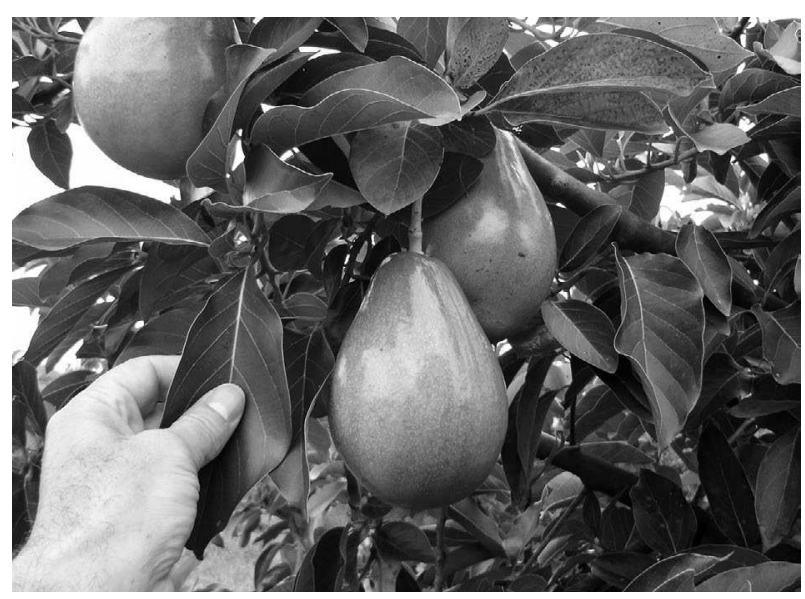

\section{ABSTRACT}

Fruit production and quality depend on adequate source-sink relationships. Carbohydrates $(\mathrm{CH})$ translocated from leaves or reserve organs are the most important for the growth and development of sink organs (mainly fruits). Up to $60 \%$ of $\mathrm{CH}$ produced daily can be lost through respiration. Carbohydrates constitute over $65 \%$ of the dry matter of tree crops. Increasing the leaf-fruit ratio generally increases fruit growth and $\mathrm{CH}$ content. Photosynthesis increases with fruit load and the leaves next to fruits are strong sources for $\mathrm{CH}$. The leaf-fruit ratio is species, cultivar and geographic location dependent. The optimal leaf area in various species is 200 $\mathrm{cm}^{2}$ per $100 \mathrm{~g}$ of fruit.

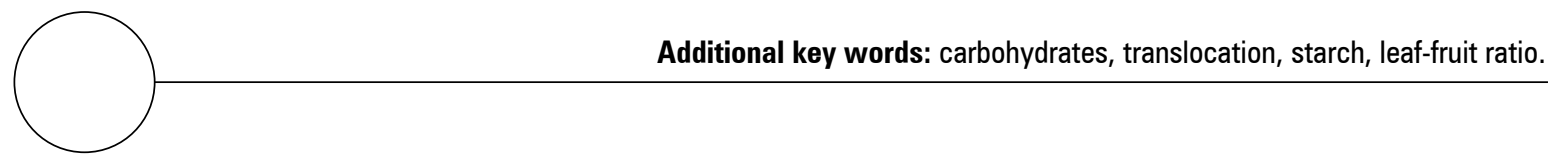

\section{RESUMEN}

La producción y calidad de frutos depende de una adecuada relación fuente-vertedero. Los carbohidratos (CH) de la planta, traslocados de las hojas o de los órganos de reserva, son de crucial importancia para el crecimiento y desarrollo de los órganos vertedero (principalmente frutos). Hasta un $60 \%$ de $\mathrm{CH}$ diariamente producidos pueden ser gastados en la respiración. Los $\mathrm{CH}$ pueden constituir más del $65 \%$ de la materia seca de los cultivos arbóreos. Con el aumento de la tasa hoja-fruto, generalmente el crecimiento del fruto y su contenido de $\mathrm{CH}$ aumentan. La fotosíntesis aumenta a medida que incrementa la carga de los frutos y las hojas cercanas a ellos son las más estimuladas. La tasa hoja-fruto depende de la especie, la variedad y de la localización geográfica. El área foliar óptima encontrada para varias especies es de $200 \mathrm{~cm}^{2}$ por $100 \mathrm{~g}$ de fruta.

Agronomy Faculty, Department of Agronomy, Universidad Nacional de Colombia, Bogota (Colombia).

2 Agricultural Faculty, Grupo de Investigación Ecofisiología Vegetal, Universidad Pedagógica y Tecnológica de Colombia, Tunja (Colombia).

3 Faculty of Science, Pontificia Universidad Javeriana, Bogota (Colombia).

4 Corresponding author: gfischer@unal.edu.co 
Palabras clave adicionales: carbohidratos, traslocación, almidón, relación hoja-fruto.

Modern fruit growers try to manipulate the source-sink relationship to guarantee adequate fruit production and quality (Gil, 2006). Balance maintenance between vegetative and generative growth of a tree is of great importance for growth and production of fruit plants (Park, 2011).

Producing and exporting organs in the plant (typically mature leaves) are known as sources, while non-photosynthetic organs (fruits, roots and tubers) and immature leaves are known as sinks (Taiz and Zeiger, 2006). Marschner (2012) pointed out that the source (supply of photosynthates) - sink (utilization of photosynthates) limitations are strongly affected by interactions between genotype and environment.

The relationship between photosynthetic and non-photosynthetic tissues is less pronounced in fruit trees than in herbaceous plants due to the structure of the tree, which implies high energy costs to maintain a notable quantity of non-photosynthetic tissue (Coleto, 1995).

DeJong and Ryugo (1998) described fruit trees as solar energy collection systems whose efficiency depends on the capture and conversion of light energy into chemical energy (photosynthesis) and later the translocation, storage, and utilization of that chemical energy. The translocation of organic materials throughout the plant in the phloem is a complex operation and therefore, this process does not have a full scientific explanation (Adams and Early, 2004).
Fruit load adjustment improves fruit quality in the same year and ensures the accumulation of reserves which can positively influence tree development for subsequent years (George et al., 1995). But, alternate fruit bearing is a major problem that can result in serious economic losses for fruit producers (Lenz, 2009). A high crop load is probably the main cause of alternate bearing (Iglesias et al., 2007). Photosynthate production is often unable to satisfy the demands during fruit set and fruit growth following heavy and prolonged flowering (Chacko et al., 1982).

The objective of this review is to elucidate sourcesink relationships in fruit plants, with special emphasis on Leaf-fruit ratio and $\mathrm{CH}$ translocation to improve our understanding of these processes in order to contribute to a possible manipulation of this relationship by growers.

\section{THE LEAF AS A SOURCE ORGAN}

Leaves are the most important organ for photosynthesis, a process which was described by Kozlowski and Pallardy (1997) in which light energy is captured by green plants (mainly by the chlorophyll in leaves) and used to synthesize reduced carbon compounds from carbon dioxide and water. Dejong and Ryugo (1998) and Friedrich and Fischer (2000) showed the influence of various factors on photosynthesis in fruit species. Photosyntesis produces $\mathrm{CH}$ for growth and energy (Lakso and Flore, 2003) and photo- 
synthates constitute up to $90 \%$ of a plant's dry matter (DM) (Daie, 1985) and both growth and cropping depend on a ready supply of carbohydrates and nutrients (Oliveira and Priestley, 1988)

There have been relatively few reports on the photosynthesis of fruit species which can differ greatly with diverse measuring methods and equipment used depending on the prevailing environmental conditions. Flore and Lakso (1989) summarized maximum photosynthetic rates (in $\mu \mathrm{mol} \mathrm{CO} \mathrm{CO}^{-2} \mathrm{~s}^{-1}$ ) for various fruit species such as the avocado (Persea americana, 4.8 \pm 2.4 ), orange (Citrus sinensis, 9.9 \pm 1.6 ), peach (Prunus persica, 13.3 \pm 3.8 ), apple (Malus domestica, 5.7 \pm 5.6 ), pear (Pyrus communis, 20.2), grapevine (Vitis vinifera, 12.4 \pm 1.4 ), blueberry (Vaccinium sp., 12.7 \pm 7.4 ) and strawberry (Fragaria $x$ ananassa, $13.9 \pm 2.9)$. Photosynthetic rates of $8.33 \mu \mathrm{mol}$ $\mathrm{CO}_{2} \mathrm{~m}^{-2} \mathrm{~s}^{-1}$ have been measured for solanaceous species such as the cape gooseberry (Physalis peruviana) on the Bogota Plateau (Melgarejo and Fischer, 2013). Medina (2003) measured photosynthetic rates of $4-8 \mu \mathrm{mol} \mathrm{CO} \mathrm{CO}^{-2} \mathrm{~s}^{-1}$ for the lulo (Solanum quitoense) in mountain rain forest conditions of Antoquia (Colombia). Leaves accumulate $\mathrm{CH}$ at a high rate, e.g., $8 \mathrm{mg} \mathrm{g}^{-1}$ day $^{-1}$ of dry weight (DW) in citrus (Citrus sp.), although leaves usually contain only a small proportion of the total amount of the fruit tree (Kozlowski and Pallardy, 1997).

$\mathrm{CH}$ metabolism change is an important event in leaf development, while young (heterotrophic) leaves depend in part on the $\mathrm{CH}$ imported from other areas of the plant, mature (autotrophic) leaves produce excess photosynthates and act as the principal source of the plant of translocated sugars (Turgeon, 1989). The import of photosynthates in dicotyledonous leaves ends at between 30 to $60 \%$ of their maximum growth but, it should be noted that developing leaves still import photosynthates although they are already exporting their own organic products (Turgeon, 1989).
The leaves close to developing fruits exhibit increased photosynthetic capacity as compared to the remaining leaves of the tree (Urban et al., 2003). In other species, the calyx has significant photosynthetic capacity, so in the cape gooseberry, the green calyx that completely covers the fruit during its development plays an important role in the production and translocation of $\mathrm{CH}$ (mainly sucrose) during the first 10 to 20 days of fruit development (Fischer and Lüdders, 1997). The fruit and calyx exhibit nearly the same $\mathrm{CH}$ composition pattern as compared to nearby leaves (Fischer, 1995) (figure 1).

Different environmental factors influence the source-sink relationship. Leaf drop effects due to stress greatly influence leaf-fruit sink-source relationships and can be caused by environmental air (temperature, storm, hail, and chemical or industrial emissions) or root (temperature, drought, salinity, oxygen deficiency) conditions (Fischer, 2011). Plants under osmotic stress (drought or salinity) adjust their leaf area through lower growth and/or leaf abscission to improve their resistance to these adverse conditions (Taiz and Zeiger, 2006). According to Goday and Pagés (2004), plants retain their intracellular water potential under mild drought conditions thanks to osmotic adjustment due to sugar accumulation without altering protein functions. Lenz (2009) found that in flooded trees, leaves drop less when they were in full fruit development, as compared to those in other physiological stages.

Because carbohydrates are removed with fruits during harvest and the leaves are the organs of high carbon uptake by the plant, after harvest, all practices that favor carbon uptake such as light and health should be optimized (Lenz, 2009), (figure 2). Fischer et al. (2010) recommended maintaining peach trees growing in the Colombian highlands with intact leaves 3-4 months after harvest, before defoliation, to improve $\mathrm{CH}$ accumulation for the next cycle. 


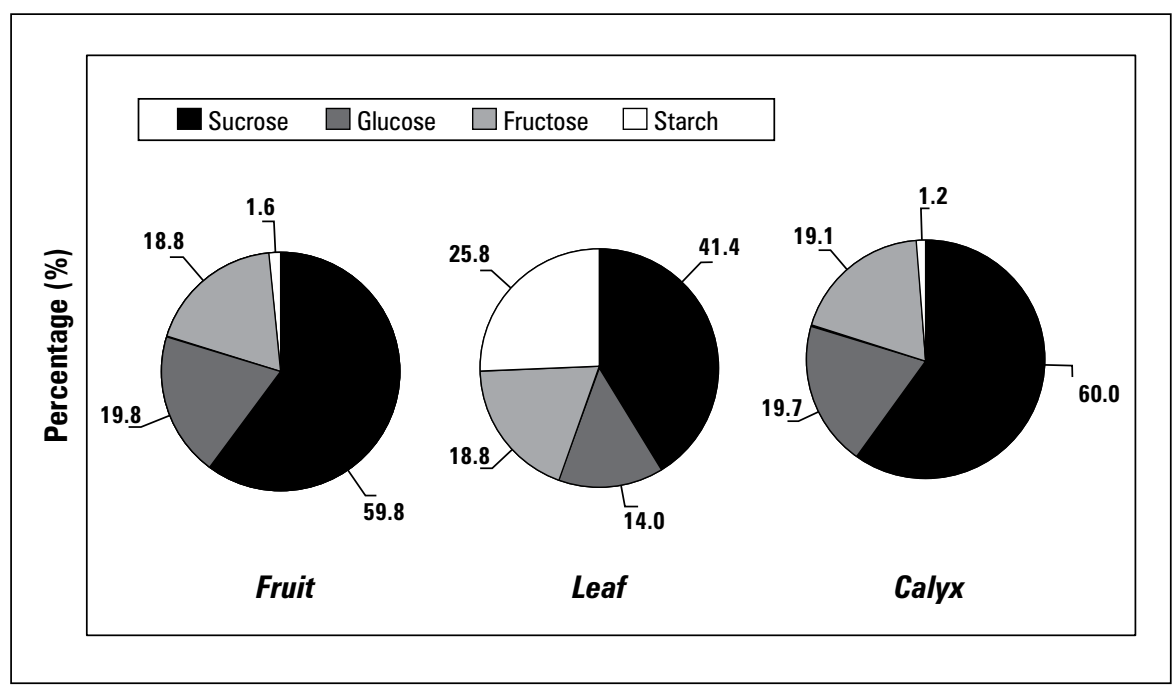

Figure 1. Percentage distribution of carbohydrates in ripe fruit, calyx and nearby leaves of the cape gooseberry (Physalis peruviana) (data from Fischer, 1995).

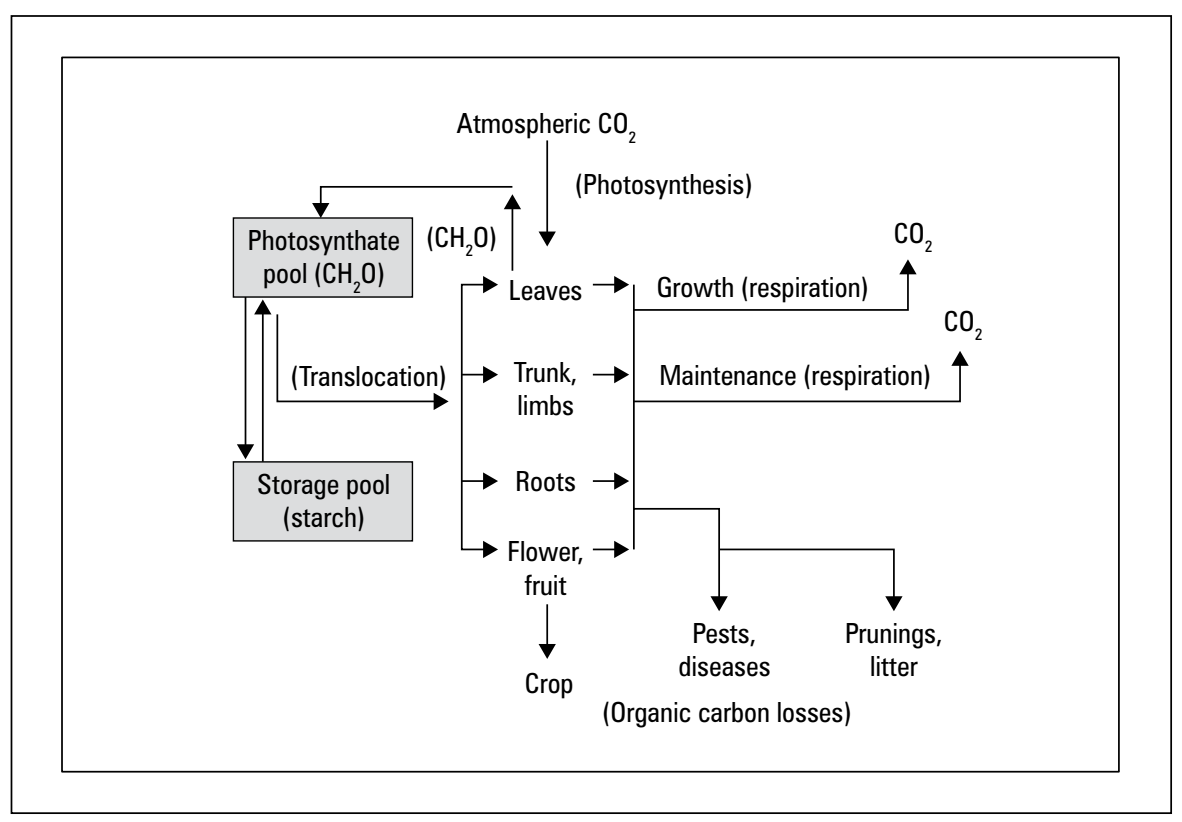

Figure 2. Diagram of carbon economy in fruit trees (after DeJong and Ryugo, 1998. This material is reproduced with permission of (CThe Regents of the University of California, Davis, CA).

Fruit removal in apple trees favors more leaf area development compared to those with intact fruits (Lenz, 2009) and subsequent fruiting in young trees reduces leaf area. Furthermore, fruitless growing strawberries produced $61.1 \%$ assimilates in leaves, but only $39.2 \%$ and $21.1 \%$ of the assimilates occurred in plants growing with 6 and 12 fruits, respectively (Friedrich and Fischer, 2000).

Defoliating trees partially increases the rate of photosynthesis in the remaining leaves because 
they provide a relatively larger sink (Kozlowski and Pallardy, 1997) and this depends on the defoliation degree. Removal of $30 \%$ of leaves in the sour cherry (Prunus cerasus) reduced photosynthesis, but when defoliated less than $30 \%$, this was offset by a higher carboxylation efficiency and a higher capacity for regeneration of ribulose-1.5-bisphosphate (Layne and Flore, 1992).

'Sunset' papaya (Carica papaya) defoliation $(50 \%)$ did not affect the total soluble solids (TSS) or the rate of set of new fruits, possibly caused by a high enough photosynthesis rate in the remaining leaves (Zhou et al., 2000). Leafremoval on citrus at the beginning of fruit cell division caused fruit abscission which increased with increasing defoliation (Agustí, 2004).

\section{Leaf area index (LAI)}

Minimum quantities of leaf area and shoot structure are required for setting large fruit crops (Lakso y Flore, 2003). Compared to annual crops (e.g., cereals), little information about the LAI (relationship between leaf area and occupied soil area) is known about fruit species. The LAI in conjunction with sunlight interception is useful as a basis for analyzing canopy productivity (Fischer, 2011).

Jackson (1980) reported that the LAI in the apple lies between 1.5 and 5 depending on the variety, rootstock, pruning, trellising, fertilization and other cultural practices. The index in the peach is generally higher, between 7 and 10 (Faust, 1989). The LAI is higher than 1.5 in the apple. Moreover, height and type of training define light penetration to the foliage (Faust, 1989). The leaf area index in the orange can be as high as 9 or 11 (Dussi, 2007). Rajan et al. (2001) found that in the tropics, some mango (Mangifera indica) cultivars well adapted to subtropical conditions develop large crowns with dense foliage, causing poor light penetration, flowering and fruit quality. These authors stud- ied canopy characteristics of 26 Indian mango varieties on 10-year-old trees, planted at $10 \times 10$ $\mathrm{m}$, measuring an average LAI of 2.94 (1.18-4.48). The fraction of the light passing through the canopy (DNI, diffuse non-interceptance) ranged from 0.02 to 0.36 (maximum is 1 ). The varieties with a low LAI and high DNI ('Fernandin', 'Papatio', 'Malihabad Safeda' and 'Rataul') were better exposed to solar radiation and produced more reproductive stems and good color fruits than varieties with denser foliage (Rajan et al., 2001).

Apart from cultural practices, agro-ecological conditions and age of plants can influence LAI development (Fischer, 2011). This is the case with cape gooseberry planted in the Boyacá department (Colombia) at $1 \times 1 \mathrm{~m}$ in Villa de Leyva $(2,300 \mathrm{~m}$ a.s.1.) and in Tunja (2,690 $\mathrm{m}$ a.s.1.) that developed, after 3 months of planting, a LAI of 14.5 at 2,300 $\mathrm{m}$ a.s.1., but only an index of 3.0 at 2,690 m, however, after 9 months of culture in both altitudes, the LAI was approximately 12.5. The rapid LAI development at 2,300 $\mathrm{m}$ a.s.l. allowed early and higher fruit production throughout the culture compared to the higher site.

\section{THE FRUIT AS A SINK ORGAN}

The development of the fruit size depends on a number of factors such as the leaf-fruit ratio, genetic and climatic factors, position in the plant and the branch, tree age, number of seeds and water and nutrient supply (Dennis, 1996). For a full crop, most fruit species will set more fruit than needed if growing conditions are optimal (Westwood, 1993).

During their development, fruits accumulate carbohydrates, generally as starch, sucrose, or hexose sugars (Kozlowski and Pallardy, 1997) which are highly dependent on the fruit maturity stage and varies according to cultivar, leaffruit ratio and growing conditions (Friedrich 
and Fischer, 2000). The breakdown of starch in mango fruit mainly leads to an increase in sucrose content rather than in glucose (Léchaudel and Joas, 2007).

The fruit attracts photosynthates and thus increases the photosynthetic production of leaves (Kozlowski and Pallardy, 1997), while few fruits in the canopy cause accumulation of photosynthates in leaves (less photosynthesis activity) (Hansen, 1982). A high fruit load can induce vegetative growth stagnation (Kozlowski and Pallardy, 1997). During full fructification, over $80 \%$ of the photosynthates can be used for fruit filling (Schumacher, 1989).

While a high fruit load decreases the distribution of assimilates to the roots and other permanent plant organs, the lack of assimilates may also have negative effects on fruit production in the following years (Lenz, 2009). Poor accumulation of reserves in persimmon (Diospyros kaki) inhibited flower induction, causing alternate bearing (Ojima et al., 1985). This same phenomenon has also been reported in the literature for species such as citrus (Goldschmidt and Golomb, 1982) and the apple (Lenz, 2009). Consequently, vegetative growth must be sufficiently vigorous to enable growth of well-illuminated leaves (Gil, 2006).

Fruits show a strong attraction for photosynthetic products and if the amount of fruit rises, the photosynthate production by leaves is higher (Kozlowski and Pallardy, 1997). Expanded leaves near the fruit exhibit increased photosynthetic rates (Urban et al., 2003). Hansen (1978) observed that the distant leaves can serve as an assimilate source and thus, the importance of having more fruits in the thinned branches.

Green and immature fruits exhibit substantial surface-to-volume ratios and refix a lot of internally respired carbon but only modest amounts of atmospheric $\mathrm{CO}_{2}$, mainly during early development (Blanke and Lenz, 1989).

\section{CARBOHYDRATES}

Simple sugars such as glucose are the principal products of photosynthesis and the basic substances from which most other organic compounds are synthesized (Kozlowski and Pallardy (1997); collectively, these compounds constitute over $90 \%$ of the whole DM of plants, while $\mathrm{CH}$ themselves can make up over $65 \%$ of the DM of tree crops (Wolstenholme and Whiley, 1989).

Soluble $\mathrm{CH}$ in fruit trees are composed of monosaccharides (normally glucose and fructose), oligosaccharides (mainly sucrose), whereas insoluble carbohydrates consist of starch and hemicelluloses (Oliveira and Priestley, 1988). Glucose is also a building block for starch, cellulose, and a substrate for synthesis of hemi-celluloses, pectins and gums (DeJong and Ryugo, 1998). Nonstructural $\mathrm{CH}$ in roots and wood fractions are important for tree longevity and quality potential during harvest (Zufferey et al., 2012).

Sucrose represents over $95 \%$ of the DW of the material that is translocated in the sieve tubes of the phloem (Kozlowski and Pallardy, 1997). Starch is undoubtedly the most common and important reserve (storage) form of $\mathrm{CH}$ in higher plants, it can accumulate up to $20 \%$ or more of the DM of some tissues and is the most useful indicator of seasonal $\mathrm{CH}$ trends in tree crops, and is most closely related to the aspects of tree performance (Wolstenholme and Whiley, 1989). Starch accumulates whenever a high level of sugar builds up; it is converted to sugars when sugar contents are low (Kozlowski y Pallardy, 1997).

The process whereby the largest fraction of $\mathrm{CH}$ is oxidized is respiration, taking place not only in the light but also in the dark (DeJong and Ryugo, 1998), releasing the energy needed in the synthetic processes associated with growth and plant metabolism (Kozlowski and Pallardy, 1997). Maintenance respiration occurs continu- 
ally in living tissues to keep them healthy and functioning, whereas growth respiration occurs to supply energy for the construction of new tissues (figure 2) (DeJong and Ryugo, 1998). Maintenance respiration losses and growth respiration account for between 30 and $60 \%$ of the daily production of $\mathrm{CH}$ (Kozlowsky and Pallardy, 1997).

\section{LEAF-TO-FRUIT TRANSLOCATION OF CARBOHYDRATES}

Generally, assimilate supply is dependent on photosynthesis (Marschner, 2012) (figure 3). The distribution (partitioning) of $\mathrm{CH}$ determines the amounts and patterns of plant growth and yield (Lakso and Flore, 2003). Translocation is dependent on the developmental state of the plant. Furthermore, transport direction and volume depend on sink position and relative attraction strength (Friedrich y Fischer, 2000). Taiz and Zeiger (2006) referred to allocation as the differential use of $\mathrm{CH}$ in metabolism, transport and storage, in the latter case, starch is synthesized and stored within chloroplasts and is the primary storage form that is mobilized (as sucrose) for translocation during the night.
Carbohydrates and other organic substances are translocated in the sieve tube elements of the phloem following the pressure-flow model as a mass flow of solution driven by an osmotically generated pressure gradient between source and sink organs (Taiz and Zeiger, 2006). Ninety percent of sap solute molecules are carbohydrates that travel at a speed of about 50-100 $\mathrm{cm} \mathrm{h}^{-1}$ (Friedrich and Fischer, 2000). The form of $\mathrm{CH}$ translocation in fruit plants is primarily sucrose, which is less reactive than reducing sugars such as glucose and fructose (Taiz and Zeiger, 2006). Important media for translocating $\mathrm{CH}$ include sugar-alcohols such as sorbitol in pomaceous fruit species (Rosaceae) (Ryugo, 1993) and mannitol in the olive (Wolstenholme and Whiley, 1989). Other materials translocated in the phloem are amino acids and proteins, hormones, and some inorganic ions (Taiz and Zeiger, 2006).

Assimilates are supplied to the fruit generally by leaf photosynthesis and plant carbohydrate reserves (Friedrich and Fischer, 2000). In the grapevine, rapid accumulation of total soluble solids (TSS) in berries at veraison is mainly due the mobilization of non-structural $\mathrm{CH}$ previously stored in the permanent organs (Zufferey et al., 2012).

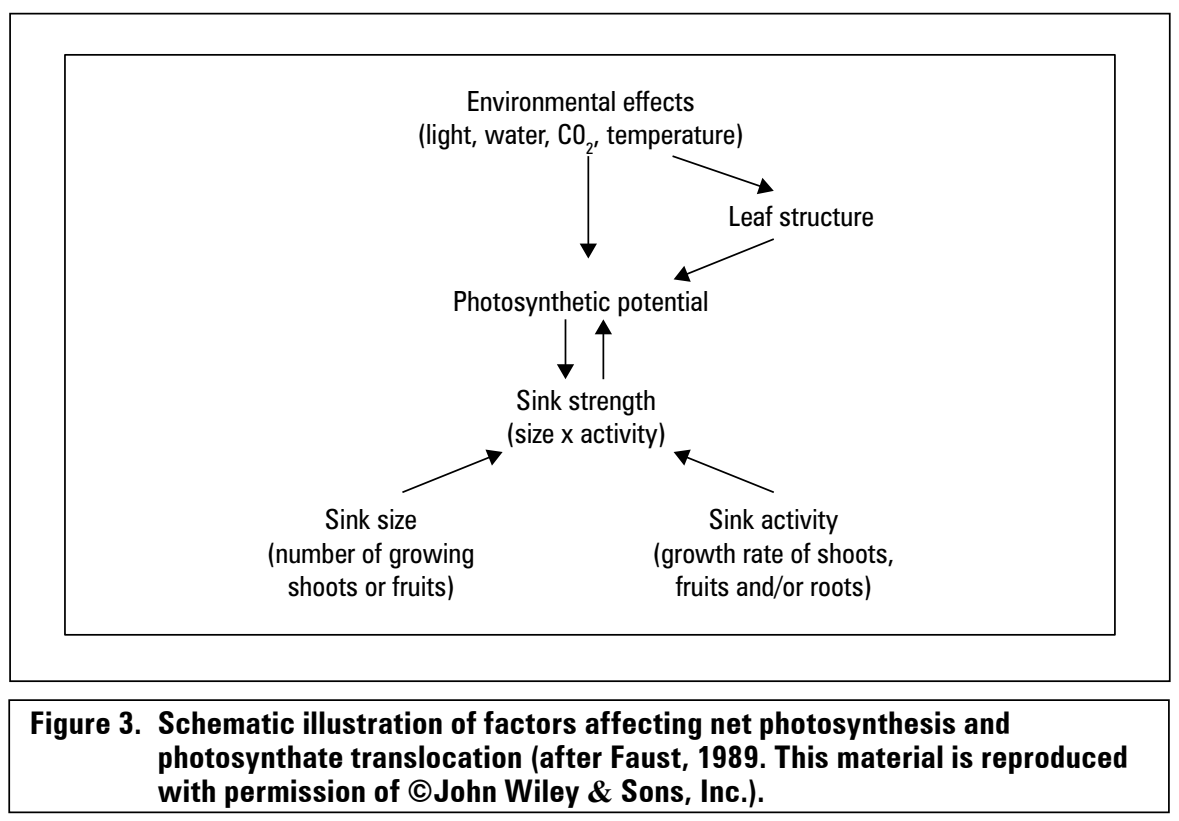

REV. COLOMB. CIENC. HORTIC. 
Leaves may export, in 6 hours, as much as 70 to $80 \%$ of the photosynthate produced within a short time (Brown, 1984). When a plant develops a heavy fruit load, the fruits seem to have a priority for the photosynthate from most leaves (Wardlaw, 1990) (figure 2), both the direction and pathway of assimilate transport change in favor of fruit growth (Ho, 1992). Generally, root and shoot apices are the principal sinks during vegetative growth, fruits generally become the dominant sinks during the reproductive phase, particularly for adjacent and nearby leaves (Taiz and Zeiger, 2006; Parra, 2003).

\section{Competition among organs}

Different tree organs compete for $\mathrm{CH}$, which are mainly produced by leaves. Fruits have a greater sink strength than other organs (table $1 \mathrm{~A}$ and D) (Wardlaw, 1990; Ho, 1996). Sink strength in plants without fruits occur in the stem (table 4B) or roots (table 4C) which predominantly attract $\mathrm{CH}$.

The upper expanded leaves export $\mathrm{CH}$ to young leaves (even importing) and cauline meristem, as the number of leaves increases, the basal leaves send photosynthates predominantly to the roots (Taiz and Zeiger, 2006).

According to Kozlowski and Pallardy (1997), the rate of translocation of photosynthates from the sources (mainly leaves) to the sinks (mainly fruits) influences photosynthesis. Carbohydrate partitioning within a tree is not a genetically programmed process, but a result of the unique combination of competing organs and their relative abilities to compete for limited carbohydrates (Lakso y Flore, 2003). The degree of competition among various sinks depends on the organ activity and distance from the $\mathrm{CH}$ source. Moreover, Parra (2003) noted that the four adjacent leaves to the tree tomato fruit were responsible for filling.

Fruits demand large quantities of photosynthates and the growth of branches and especially the root system decrease as the fruit load increases (Lakso and Flore, 2003). Fruit-growing trees build more dry matter per unit leaf area than plants without fruit (Lenz, 2009). Leaves closest to the fruit have a dominating photosynthetic activity and, moreover, high transpiration rates and stomatal opening (Herold, 1980).

Shoots and roots of young trees receive considerable amounts of $\mathrm{CH}$, the relative amount that roots receive however, tends to decline with tree age and with heavy fruit loads, partitioning of $\mathrm{CH}$ to the roots reduces dramatically (Lakso and Flore, 2003; Lenz, 2009). On the contrary, in the semi-woody and fruiting cape gooseberry plant, characterized by an indeterminate growth habit, the highest amount of starch reserve is found in the roots and basal stem (Fischer et al., 2008).

The behavior of $\mathrm{CH}$ translocation of the wine grape, during the beginning of the season, is

Table 1. Hierarchies among sink organs in descending order (A and B: Wardlaw [1990] for plants in general; C and D: Ho [1996] for the tomato).

\begin{tabular}{|c|c|c|c|}
\hline A. Fruits, bulbs, tubers & B. Stem & C. Roots & D. Fruits \\
\hline$\vee$ & $\vee$ & $\vee$ & $\vee$ \\
\hline Seeds & Roots & Young leaves & Young leaves \\
\hline$\vee$ & & $\vee$ & Roots \\
\hline Vegetative & & Flowers & \\
\hline meristems & & & \\
\hline$\vee$ & & & \\
\hline Flowers & & & \\
\hline
\end{tabular}


acropetal (apical) and when leaves are mature, $\mathrm{CH}$ translocate to fruit clusters and finally $\mathrm{CH}$ transport is basipetal (Agustí, 2004). Species and cultivars with an indeterminate growth habit (Passifloraceae, Solanaceae and Caricaceae), in which the vegetative phase overlaps with the reproductive phase, balance their supply to both sink types (vegetative and reproductive) (Fischer, 2005).

Fruits closer to the main stem have a tendency to become larger because they better compete for $\mathrm{CH}$, and the farthest from the main stem become smaller because they have less of a chance to compete, as confirmed in the cape gooseberry by Mazorra et al. (2003). The exceptions are the fruit produced in the periphery of the canopy which take advantage of direct sunlight, both on the fruits and the adjacent leaves, as compared to those growing under the canopy (Kozlowski and Pallardy, 1997). Hansen (1978) found higher translocation rates of photosynthates and fruit growth with exposure to full sun conditions in contrast to deficient light conditions within the canopy.

\section{Harvest index}

The harvest index (HI) is used in crop physiology as the percentage of total DM partitioned to the harvested portion (the fruit) (Lakso y Flore, 2003). The HI increases with the age of the fruit tree and depends on various factors such as variety, root stock, agro-ecological conditions and crop management. For apple trees in production, the HI (including root system) can be between 30 and $50 \%$, which can go up to 65 and $80 \%$ in very favorable conditions, and in peach trees, it can reach 70\% (Lakso and Flore, 2003), as compared to annual field crops with HI values of 20-50\% (excluding root system).

\section{Some external factors}

Temperature plays an important role in $\mathrm{CH}$ partitioning (Fischer, 2011). The optimum temperature for transporting $\mathrm{CH}$ in most species is be- tween 20 and $30^{\circ} \mathrm{C}$ and, according to Guardiola and Garcia-Luis (1993), translocation diminishes with decreasing temperatures (due to the viscosity of the phloem solution); however, in species not sensitive to low temperature conditions, the sieve tubes are functional at temperatures close to the freezing point and even lower.

Night temperature is of great importance for $\mathrm{CH}$ translocation. This is because $\mathrm{CH}$ are translocated during night hours and therefore, as in the case of the Rosaceae, it has been reported that growth occurs more during the night than in the day (Fischer, 2011). Khayat and Zieslin (1986) found that roses exposed to low night temperatures $\left(12^{\circ} \mathrm{C}\right)$ reduced sugar transport to axillary buds by increasing levels of starch and sucrose in the leaves. Storage of photosynthates in leaves increases as a result of slow growth and low $\mathrm{CH}$ demand during low temperatures below the optimum range (Fischer, 2011).

Water stressed plants delay $\mathrm{CH}$ transport due to an increase in the viscosity of the solution translocated (Barceló et al., 1992). Prolonged water deficits cause the accumulation of abscisic acid, a hormone that inhibits phloem loading in leaves (Guardiola and García-Luis, 1993).

The distribution of assimilates may be affected by a deficiency or imbalance of mineral nutrients and, furthermore, by the initiation and development of sink organs and for source functioning, the plant requires an adequate supply of nutrients (Taiz and Zeiger, 2006).

Potassium is claimed to be essential in the process of loading and unloading the phloem (due to high concentrations of $\mathrm{K}$ in companion cells of sieve elements) (Taiz and Zeiger, 2006). Potassium deficiency affects vegetative growth because the plant alters the distribution of $\mathrm{K}$ to improve the growth of the fruit (Ho, 1996). Léchaudel and Joas (2007) found higher K and $\mathrm{Mg}$ concentrations in the flesh of mango fruit with higher leaf-to-fruit ratios. In contrast, bo- 
ron does not facilitate sugar transport via the formation of borate-sugar complexes, because sucrose builds only weak complexes with B and, additionally, B is not involved in sucrose phloem loading (Marschner, 2012).

\section{LEAF-FRUIT RATIO}

The optimum exposure of the maximum number of leaves to light normally results in the greatest yield of DM (DeJong and Ryugo, 1998). Optimal leaf-to-fruit ratio varies according to the species and variety, and orchard geographic location (Schumacher, 1989). Moreover, the capacity of leaf photosynthesis depends on the incidence of light, whereby the shaded parts of the canopy assimilate less and need more leaves than the well illuminated part for optimal fruit development. Schumacher (1989) considered that the leaf-fruit ratio is not totally reliable. Hansen (1978) stated that decreasing the leaf-fruit ratio increases the photosynthetic efficiency of the leaves, causing a raised sink-effect.

Tree fruits with a high leaf-to-fruit ratio, as in young plants or those with a low fruit load, often form large fruits with a "spongy" tissue which reduces postharvest life and increases susceptibility to diseases (Fischer and Friedrich, 2000). As fruit density increases, the leaf-tofruit ratio decreases, resulting in a lower supply of photosynthate per fruit; fruit size therefore decreases (Dennis, 1996; figure 4), along with insufficient color and flavor (Schumacher, 1989).

Optimal leaf area in several fruit species is 200 $\mathrm{cm}^{2}$ per $100 \mathrm{~g}$ of fresh fruit mass for favorable growth and quality (Fischer, 2011). Furthermore, grapes require twice this value (table 2). The increase in leaf-fruit ratio may facilitate the accumulation of starch reserves, favoring vegetative growth and fruiting in the following season (Chacko et al., 1982). Grapevines doubled the root starch concentration from 12 to $25 \%$ DW when the leaf-fruit ratio increased from 0.5 to $2.0 \mathrm{~m}^{2}$ of light-exposed leaf area per $\mathrm{kg}$ fruit (Zufferey et al., 2012).

The rate of sucrose accumulation for the Satsuma mandarin in the fruit was higher at a normal load (25 leaves/fruit), as compared to trees with 50 leaves per fruit (thinning at 70 days after anthesis) (Kubo et al., 2001). Thinning of 10, 25, 50,

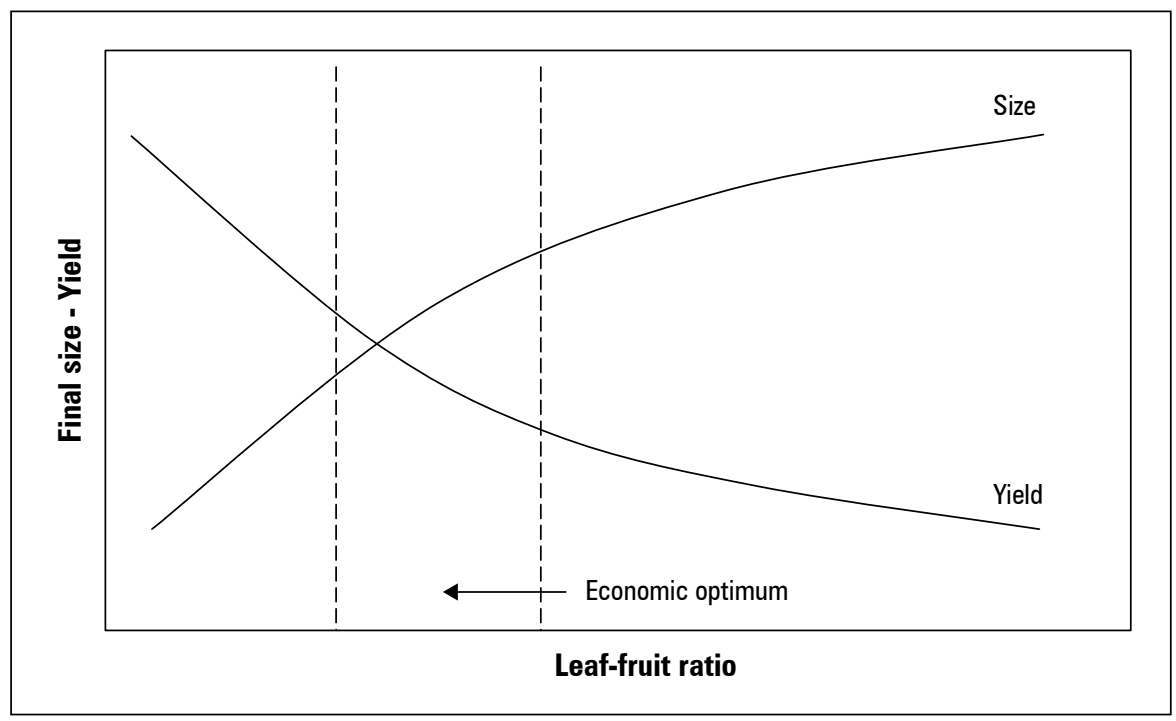

Figure 4. Effect of leaf-fruit ratio on size and yield of fruits (diagrammatic) (after Dennis, 1996. This material is reproduced with permission from Frank G. Dennis). 
100 and 150 leaves per fruit in the mango 'Lirfa' (grafted on 'Maison Rouge') resulted in the highest fresh weight of fruit at 100 leaves, while flesh DW increased $11 \%$, when the number of leaves increased from 10 to 100 (Léchaudel et al., 2004). Casierra-Posada et al. (2007) observed increased TSS content and pulp/stone ratio in the 'Rubidoux' peach with thinning increase, with optimal fruit quality at 40-50 leaves/fruit.

Sauer and Baumann (2007) trained the vine with 4-5 canes $/ \mathrm{m}^{2}$ and a foliage height of 1.20 to $1.40 \mathrm{~m}$ in vertical trellis system and obtained seven leaves (on the main branch) by the cluster of vine grapes in the region of Franken (South Germany). This relationship could be larger in varieties with large berries (8-10 leaves/cluster) (Petgen, 2007). The leaf-fruit ratio changes with the production area latitude in which the temperature and light have the greatest influence, with lower ratios at sites nearer to the equator (Fischer, 2011). Sauer and Baumann (2007) reported that under the conditions of Franken, for the production of $1 \mathrm{~g}$ of berries, $20 \mathrm{~cm}^{2}$ of leaf area are needed (for $1 \mathrm{~kg} 2 \mathrm{~m}^{2}$ ).
The 'Riesling x Silvaner' grapevine in Corrales (Boyacá) responded favorably to cluster thinning as an alternative to improve production and quality of the wine grapes; $33 \%$ thinning of fruit clusters (without leaf removal) at the time of fruit set improved TSS concentration of berries, and increased fresh mass of clusters and fruits (Almanza-Merchan et al., 2011) (figure 5). Defoliation of $60 \%$, in general, resulted in lower $\mathrm{pH}$ values and technical maturity index and higher TSS content and titratable acidity in berries, as compared with non-defoliated plants (figure 5). Berkey et al. (2011) stated that crop load reduction techniques in grapevines may only be economically justified in varieties that have a propensity for overcropping.

Growers can rely on a number of methods which directly or indirectly influence photosynthesis and sink activity (fruit growth). Among these, the most important are tree height, distance, fruit thinning, pruning, fertilization, application of growth regulators, irrigation and phytosanitary control (Flore and Lakso, 1989; Fischer, 2005). Girdling

Table 2. Examples of leaf number and leaf area for optimal production of one fruit, depending on cultivar and agroecological growth conditions.

\begin{tabular}{|c|c|c|c|c|}
\hline Crop & Species & No. of leaves/fruit & Leaf area-fruit ratio & Author \\
\hline Lulo & Solanum quitoense & $1 / 4-1 / 2$ & & $\begin{array}{l}\text { Cabezas and Novoa } \\
(2000)\end{array}$ \\
\hline Tree tomato & Solanum betacea & 4 & $214 \mathrm{~cm}^{2} / 100 \mathrm{~g}$ fruit & Parra (2003) \\
\hline Cape gooesberry & Physalis peruviana & $1-2$ & & Fischer (2005) \\
\hline Pineapple guava & Acca sellowiana & 7 & $146 \mathrm{~cm}^{2} /$ fruit & $\begin{array}{l}\text { Orjuela and Barreto } \\
(2009)\end{array}$ \\
\hline Pineapple & Ananas comosus & $6-8^{1}$ & & Malézieux et al. (2003) \\
\hline Mango & Mangifera indica & $30-60^{2}$ & & Fischer (2005) \\
\hline Japanese plum & Prunus salicina & $15-25$ & & Fischer (2005) \\
\hline Peach & Prunus persica & $15-30$ & & Fischer (2005) \\
\hline Apple & Malus domestica & $15-35$ & $200 \mathrm{~cm}^{2} / 100 \mathrm{~g}_{\text {fruit }}{ }^{3}$ & Fischer (2005) \\
\hline Pear & Pyrus communis & $25-40$ & & Fischer (2005) \\
\hline Grapevine & Vitis vinifera & $7-8^{4}$ & $\begin{array}{l}2 \mathrm{~m}^{2} / 1 \mathrm{~kg} \text { fruit } \\
\left(2,000 \mathrm{~cm}^{2} / 100 \mathrm{~g} \text { fruit) }\right.\end{array}$ & $\begin{array}{l}\text { Sauer and Baumann } \\
(2007)\end{array}$ \\
\hline Satsuma mandarin & Citrus unshiu & 25 & & Kubo et al. (2001) \\
\hline
\end{tabular}

${ }^{1}$ Leaf number at floral induction; ${ }^{2} 60$ leaves in varieties with alternant bearing; ${ }^{3}$ Faust (1989); ${ }^{4}$ Leaves/cluster. 
(branch ringing), the removal of a bark ring in the trunk or in the base of lateral growth axes, interrupts photosynthate flow to the roots and thereby increases flower induction and fruit filling, apparently through increased sugar availability in the aerial parts of the tree (Iglesias et al., 2007); and is not yet common in
Colombian fruticulture. A preliminary study in the Colombian coffee zone indicated that ringing ( $5 \mathrm{~mm}$ wide) in the base of productive main branches of 'Sweety Orange' trees, 3 weeks after anthesis, increased fruit retention by $38 \%$, as compared to non-ringed trees (Cabezas-Gutiérrez and Rodríguez, 2010).

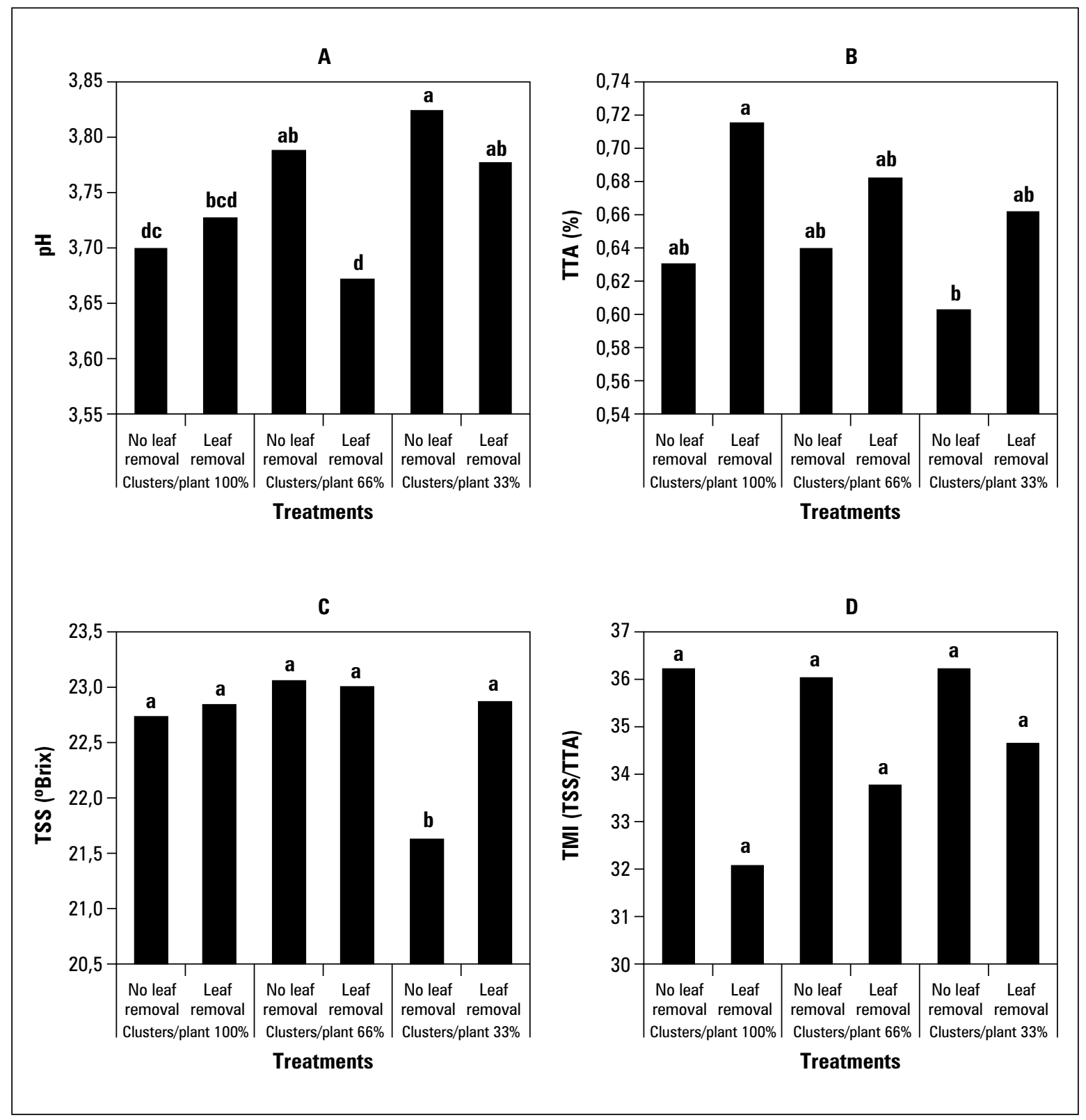

Figure 5. Effect of leaf removal and cluster thinning in Vitis vinifera plants on: A. pH, B. Total titratable acidity (TTA), C. Total soluble solids (TSS), and D. Technical maturity index (TMI). Means followed by different letters differ significantly according to Tukey's test $(P \leq 0.05 \%)$ (after Almanza-Merchán et al., 2011. This material is reproduced with permission of Agronomía Colombiana, (CUniversidad Nacional de Colombia, Facultad de Agronomía). 
Training and pruning alters the balance between vegetative growth and reproductive fruiting by the allocation of resources, such as carbohydrates, water and growth regulators (Myers, 2003). Heavy pruning diminishes leaf area, whole tree photosynthesis and translocation of photosynthates to fruits and roots, increasing the root/shoot ratio (Casierra-Posada and Fischer, 2012) and favoring vegetative growth. In guava (Psidium guajava), mid- and light pruning provide greater fruit weight ratios in contrast to heavy pruning (Serrano et al., 2007). During the reproductive phase, "fruiting pruning" is used because this pruning type improves fruit load, regulates the physiological balance (vegetative-reproductive), ensures a harmonious and rational distribution of high quality production, maintains a constant production over time, and contributes to fruit thinning (Arjona and Santinoni, 2007). In pruning, it is important to cut off (thinning) upright water sprouts which direct photosynthates, among other substances, to the growing shoot tip at the expense of reproductive growth (Myers, 2003).

\section{CONCLUSIONS}

Photosynthesizing organs, known as sources, mainly mature leaves, produce photosynthates, mainly carbohydrates, translocated by the sieve tubes of the phloem to non-photosynthetic organs (fruits, roots and tubers) and immature leaves, known as sinks. High, yearly, constant yields and fruit quality require an adequate leaffruit ratio (number of leaves, certain leaf area per fruit or fresh weight unit). Growers can obtain adequate leaf-fruit-ratios with a reliable canopy and plant management system. Decreasing leaf-fruit ratios increase the photosynthetic efficiency of the leaves but flower induction for the next growth cycle is lower. In contrast, a high leaf-fruit ratio assures a sufficient storage supply, mainly starch, for the following crop.

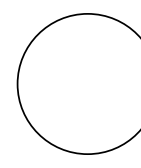

Adams, C.R. and M.P. Early. 2004. Principles of horticulture. $4^{\text {th }}$ ed. Elsevier Butterworth-Heinemann, Oxford, UK.

Agustí, M. 2004. Fruticultura. Ediciones Mundi-Prensa, Madrid.

Almanza-Merchán, P.J., G. Fischer, P.A. Serrano-Cely, H.E. Balaguera-López, and J.A. Galvis. 2011. The effects of leaf removal and cluster thinning on yield and quality of grapes (Vitis vinifera L., Riesling x Silvaner) in Corrales, Boyaca (Colombia). Agron. Colomb. 29(1), 35-42.

Arjona, C. y L.A. Santinoni. 2007. Poda de árboles frutales. pp. 243-282. In: Sozzi, G.O. (ed.). Árboles frutales, ecofisiología, cultivo y aprovechamiento. Universidad de Buenos Aires, Buenos Aires.

Barceló, J., G.N. Rodrigo, B. Sabater, and R. Sanchez. 2000. Fisiología vegetal. Ed. Pirámide, Madrid.

Berkey, T.G., A.K. Mansfield, S.D. Lerch, J.M. Meyers, and J.E. Vanden Heuvel. 2011. Crop load adjust-

\section{BIBLIOGRAPHIC REFERENCES}

ment in 'Seyval Blanc' winegrape: Impacts on yield components, fruit composition, consumer wine preferences, and economics of production. HortTechnol. 21(5), 593-598.

Blanke, M.M. and F. Lenz. 1989. Fruit photosyntheis - a review. Plant Cell Environ. 12, 31-46.

Brown, R.H. 1984. Growth of the green plant. pp. 153-174. In: Physiological basis of crop growth and development. American Society of Agronomy, Crop Science Society of America, Madison,WI.

Cabezas, M. and D.L. Novoa. 2000. Efecto de la remoción de hojas y frutos en la relación fuente demanda de asimilados en lulo (Solanum quitoense). pp. 68-74. In: Proc. $3^{\text {th }}$ Seminar Frutales de Clima Frío Moderado, Manizales, Colombia.

Cabezas-Gutiérrez, M. and C.A. Rodríguez. 2010. Técnicas hortícolas para optimizar el tamaño y la calidad del naranjo (Citrus sinensis L.). Agron. Colomb. 28, 55-62. 
Casierra-Posada, F. y G. Fischer. 2012. Poda de árboles frutales. pp. 169-185. In: Fischer, G. (ed.). Manual para el cultivo de frutales en el trópico. Produmedios, Bogotá.

Casierra-Posada, F., J.I. Rodríguez, and J. CárdenasHernández. 2007. La relación hoja:fruto afecta la producción y la calidad del fruto en duraznero (Prunus persica L. Batsch, cv. Rubidoux). Rev. Fac. Nal. Agr. Medellin 60(1), 3657-3669.

Chacko, E.K., Y.T.N. Reddy, and T.V. Ananthanarayanan. 1982. Studies on the relationship between leaf number and area and development in mango (Mangifera indica L.). J. Hort. Sci. 57(4), 483-492.

Coleto, J.M. 1995. Crecimiento y desarrollo de las especies frutales. Ed. Mundi-Prensa, Madrid.

Daie, J. 1985. Carbohydrate partitioning and metabolism in crops. Hort. Rev. 7, 69-108.

Dennis, F.G. 1996. Fruit development. pp. 107-116. In: Maib, K.M., P.L. Andrews, G.A. Lang, and K. Mullinix (eds.). Tree fruit physiology: growth and development. Good Fruit Grower, Yakima, WA.

DeJong, T.M. and K. Ryugo. 1998. Carbohydrate assimilation, translocation, and utilization. pp. 109-114. In: Ramos, D.E. (ed.). Walnut production manual. UC ANR Publication 3373 (http://anrcatalog.ucdavis.edu/Nuts/3373.aspx). University of California, Oakland, CA.

Dussi, M.C. 2007. Intercepción y distribución lumínica en agro-sistemas frutícolas. pp. 200-241. In: Sozzi, G. (ed.). Árboles frutales: ecofisiología, cultivo y aprovechamiento. Editorial Facultad de Agronomía, Universidad de Buenos Aires, Buenos Aires.

Faust, M. 1989. Physiology of temperate zones fruit trees. John Wiley and Sons, New York, NY.

Fischer, G. 1995. Effect of root zone temperature and tropical altitude on the growth, development and fruit quality of cape gooseberry (Physalis peruviana L.). Ph.D. thesis. Humboldt-Universität zu Berlin, Berlin.

Fischer, G. 2005. Aspectos de la fisiología aplicada de los frutales promisorios en cultivo y poscosecha. Rev. Comalfi 32(1), 22-34.

Fischer, G. 2011. La relación hoja/fruto en especies frutícolas. pp. 40-53. Proc. $4^{\text {th }}$ Colombian Congress of Horticulture, Palmira, Colombia.

Fischer, G., F. Beran, and Ch. Ulrichs. 2008. Partitioning of non-structural carbohydrates in the fruiting cape gooseberry (Physalis peruviana L.) plant. p. 145. In: Book of abstracts, Tropentag 2008. Stuttgart-Hohenheim, Germany.
Fischer, G., F. Casierra-Posada, and C. Villamizar. 2010. Producción forzada de duraznero (Prunus persica (L.) Batsch) en el altiplano tropical de Boyacá (Colombia). Rev. Colomb. Cienc. Hortíc. 4(1), 19-32.

Fischer, G. and P. Lüdders. 1997. Developmental changes of carbohydrates in cape gooseberry (Physalis peruviana L.) fruits in relation to the calyx and the leaves. Agron. Colomb. 14(2), 95-107.

Flore, J.A. and A.N. Lakso. 1989. Environmental and physiological regulation of photosynthesis in fruit crops. Hort. Rev. 36, 111-157.

Friedrich, G. and M. Fischer. 2000. Physiologische Grundlagen des Obstbaues. Ulmer Verlag, Stuttgart, Alemania.

George, A.P., R.J. Nissen, R.J. Collins, and T.S. Rasmussen. 1995. Effects of fruit thinning, pollination and paclobutrazol on fruit set and size of persimmon (Diospyros kaki L.) in subtropical Australia. J. Hort. Sci. 70, 477-484.

Gil, G.F. 2006. Fruticultura: La producción de fruta de climas templados y subtropical y uva de vino. Ediciones Universidad Católica de Chile, Santiago.

Goday, A. and M. Pagés. 2004. Proteínas de respuesta al estrés hídrico. 791-831. In: Reigosa, M., N. Pedrol, and A. Sánchez (eds.). La ecofisiología vegetal. Una ciencia de síntesis. Editoral Thomson, Madrid.

Goldschmidt, E.E. and A. Golomb. 1982. The carbohydrate balance of alternate bearing in citrus trees and the significance of reserves for flowering and fruiting. J. Amer. Soc. Hort. Sci. 107, 206-208.

Guardiola, J.L. and A. García-Luis. 1993. Transporte de azúcares y otros asimilados. pp. 149-171. In: Azcón-Bieto, J. and M. Talón (eds.). Fisiología y bioquímica vegetal. McGraw-Hill Interamericana de España, Madrid.

Hansen, P. 1978. Blatt/Frucht-Verhältnisse, Assimilatverteilung und Fruchtentwicklung. Erwerbsobstbau $20,228-231$.

Hansen, P. 1982. Assimilation and carbohydrate utilization in apple. pp. 257-268. In: Proc. 21 $1^{\text {st }}$ Int. Hort. Cong. Vol. 1.

Herold, A. 1980. Regulation of photosynthesis by sink activity - the missing link. New Phytol. 86, 131144.

Ho, L.C. 1996. The mechanism of assimilate partitioning and carbohydrate compartmentation in fruit in relation to the quality and yield of tomato. J. Exp. Bot. 47, 1239-1243. 
Iglesias, D.J., M. Cercós, J.M. Colmenero-Flores, M.A. Naranjo, G. Ríos, E. Carrera, O. Ruiz-Rivero, I. Lliso, R. Morillon, F.R. Tadeo, and M. Talón. 2007. Physiology of citrus fruiting. Braz. J. Plant Physiol. 19(4), 333-362.

Jackson, J.E. 1980. Light interception and utilization by orchard systems. Hort. Rev. 2, 208-267.

Khayat, E. and N. Zieslin. 1986. Effect of different night temperature regimes on the assimilation, transport and metabolism of carbon in rose plants. Physiol. Plant. 67, 608-613.

Kozlowski, T.T. and S.G. Pallardy. 1997. Physiology of woody trees. $2^{\text {nd }}$ ed. Academic Press, San Diego, CA.

Kubo, T., I. Hohjo, and S. Hirat. 2001. Sucrose accumulation and its related enzyme activities in the juice sacs of Satsuma mandarin fruit from trees with different crop loads. Sci. Hortic. 91(3-4), 215-225.

Lakso, A.N. and J.A. Flore. 2003. Carbohydrate partitioning and plant growth. pp. 21-30. In: Baugher, T.A. and S. Singh (eds.). Concise encyclopedia of temperate tree fruit. Food Products Press, New York, NY.

Layne, D.R. and J.A. Flore. 1992. Photosynthetic compensation to partial leaf area reduction in sour cherry. J. Amer. Soc. Hort. Sci. 117, 279-286.

Léchaudel, M., M. Jannoyer, and M. Génard. 2004. Effects of the leaf:fruit ratio on growth and partitioning of water and dry matter in mango fruit. Acta Hort. 645, 429-433

Léchaudel, M. and J. Joas. 2007. An overview of preharvest factors influencing mango fruit growth, quality and postharvest behaviour. Braz. J. Plant Physiol. 19, 287-298.

Lenz, F. 2009. Fruit effects on the dry matter and carbohydrate distribution in apple tree. Acta Hort. 835, 21-38.

Malézieux, E., F. Cote, and D.P. Bartholomew. 2003. Crop environment, plant growth and physiology. pp. 69-107. In: Bartholomew, S.P., R.E. Paull, and K.G. Rohrbach (eds.). The pineapple: Botany, production and uses. CABI Publishing, Wallingford, UK.

Marschner, P. (ed.). 2012. Marschner's mineral nutrition of higher plants. $3^{\text {th }}$ ed. Elsevier, Oxford, UK.

Mazorra, M.F., A.P. Quintana, D. Miranda, G. Fischer, and B. Chaves. 2003. Análisis sobre el desarrollo y la madurez fisiológica del fruto de la uchuva (Physalis peruviana L.) en la zona de Sumapaz (Cundinamarca). Agron. Colomb. 21(3), 175-189.
Medina, C.I. 2003. Estudio de algunos aspectos fisiológicos del lulo (Solanum quitoense Lam.) en el bosque húmedo montaño bajo del oriente antioqueño. M.Sc. thesis. Universidad Nacional de Colombia, Medellin, Colombia.

Melgarejo, L.M. and G. Fischer. 2013. Ecophysiological response of cape gooseberry (Physalis peruviana L.) to the environmental conditions of the Bogota Plateau (in preparation).

Myers, S.C. 2003. Training and pruning principles. pp. 339-345. In: Baugher, T.A. and S. Singha (eds.). Concise encyclopedia of temperate tree fruit. Food Products Press, New York, NY.

Ojima, M., F.A.C. Dall'Orta, W. Barbosa, A.F.C. Tombolata, and O. Rigitano. 1985. Alternate bearing in the persimmon cultivar Pomelo (IAC 6-22). Bragantia 44, 481-486.

Oliveira, C.M. y C.A. Priestley. 1988. Carbohydrate reserves in deciduous fruit trees. Hort. Rev. 10, 403 430.

Orjuela, N. y E. Barreto. 2009. Determinación del área foliar óptima para el llenado de frutos en feijoa (Acca sellowiana Berg) en el clon Quimba 41. Undergraduate thesis. Agronomy Faculty. Universidad Nacional de Colombia, Bogotá.

Park, S.J. 2011. Dry weight and carbohydrate distribution in different tree parts as affected by various fruit-loads of young persimmon and their effect on new growth in the next season. Sci. Hortic. 130, 732-736.

Parra, G.S. 2003. Estudio de la relación fuente vertedero en tomate de árbol (Cyphomandra betacea). M.Sc. thesis. Agronomy Faculty, Universidad Nacional de Colombia, Bogota.

Petgen, M. 2007. Reaktion der Reben auf den Klimawandel. Schweiz. Zeitschr. Obst Weinbau 9, 6-9.

Rajan, S., R. Kumar, and S.S. Negi. 2001. Variation in canopy characteristics of mango (Mangifera indica L.) cultivars from diverse eco-geographical regions. J. Appl. Hort. 3(2), 95-97.

Sauer, E. and A. Baumann. 2007. Qualitätsoptimierung durch Entblätterung. In: http://www.lwg. bayern.de/weinbau/berufsausbildung_qualifizierung/18385/ linkurl_0_15_0_1. pdf; consulted: October 2011.

Schumacher, R. 1989. Die Fruchtbarkeit der Obstgehölze. Ulmer Verlag, Stuttgart, Germany.

Serrano, L.A.L., C.S. Marinho, C.P. Ronchi, I.M. Lima, M.V.V. Martins, and F.D. Tardin. 2007. Goiabeira 'Paluma' sob diferentes sistemas de cultivo, épocas 
e intensidades de poda de frutificação. Pesq. Agropec. Bras. 42(6), 785-792.

Taiz, L. and E. Zeiger. 2006. Plant physiology. $4^{\text {th }}$ ed. Sinauer Associates, Sunderland, MA.

Turgeon, R. 1989. The sink-source transition in leaves. Annu. Rev. Plant Physiol. Plant Mol. Biol. 40, 119138.

Urban, L., X. Le Roux, H. Sinoquet, S. Jaffuel, and M. Jannoyer. 2003. A biochemical model of photosynthesis for mango leaves: evidence for the effect of fruit on photosynthesis capacity of nearby leaves. Tree Physiol. 23, 289-300.

Wardlaw, I.A. 1990. The control of carbon partitioning in plants. New Phytol. 116, 341-381.
Westwood, M.N. 1993. Temperate-zone pomology. $3^{\text {th }}$ ed. Timber Press, Portland, OR.

Wolstenholme, B.N. and A.W. Whiley. 1989. Carbohydrate and phenological cycling as management tools for avocado orchards. SA Avocado Growers' Assoc. Yrb. 12, 33-37.

Zhou, L., D.A. Christopher, and R.E. Paull. 2000. Defoliation and fruit removal effects on papaya fruit production, sugar accumulation, and sucrose metabolism. J. Amer. Soc. Hort. Sci. 125(5), 644-652.

Zufferey, V., F. Murisier, P. Vivin, S. Belcher, F. Lorenzini, J.L. Spring, and O. Viret. 2012. Carbohydrate reserves in grapevine (Vitis vinifera L. 'Chasselas'): the influence of the leaf to fruit ratio. Vitis 51, 103-110. 